\title{
Dukungan Sosial Teman Virtual Melalui Media Instagram pada Remaja Akhir
}

\author{
Ainun Rachmawati ${ }^{1}$, Yuni Nurhamida ${ }^{2}$ \\ ${ }^{1,2}$ Fakultas Psikologi, Universitas Muhammadiyah Malang \\ e-mail: ${ }^{1}$ ainunrachmawatii@gmail.com, ${ }^{2}$ y_nurhamida@yahoo.com
}

\begin{abstract}
Abstrak. Remaja akhir sendiri memiliki kebutuhan untuk berkomunikasi dengan teman sebaya, sehingga media instagram menjadi kebutuhan sehari-hari. Media instagram merupakan kemajuan teknologi yang perlahan menggeser sosialisasi secara langsung menjadi virtual. Dukungan sosial teman virtual yaitu dukungan sosial yang didapat melalui dunia maya. Tujuan dari penelitian ini untuk menggambarkan dukungan sosial teman virtual melalui media instagram. Subjek penelitian berjumlah 428 mahasiswa dengan metode pengambilan data purposive sampling. Pengumpulan data dalam penelitian ini menggunakan kuisoner berdasarkan bentuk dukungan yaitu bentuk dukungan sosial instrumental, informasional, emosional, penghargaan diri dan jaringan sosial. Hasil dari penelitian ini yaitu bentuk dukungan tertinggi pada dukungan instrumental berjumlah 86,9 \%, urutan kedua yaitu bentuk dukungan informasional berjumlah 79,7 \%, urutan ketiga yaitu bentuk dukungan jaringan sosial berjumlah 56,5 $\%$, diurutan keempat bentuk dukungan penghargaan berjumlah $34,8 \%$ dan diuruta kelima bentuk dukungan emosional berjumlah $23,6 \%$.
\end{abstract}

Kata kunci : dukungan sosial teman virtual, instagram, remaja akhir

Abstract. Late teens themselves have a need to communicate with peers, so that instagram media into their daily needs. Media instagram is slowly shifting technological advances directly into a virtual socialization. Social support virtual friends that social support is obtained through cyberspace. The purpose of this study to describe the social support virtual friends via instagram media. Subjects numbered 428 students with purposive sampling method of data collection. Collecting data in this study using a questionnaire based on the form of support is a form of social support instrumental, informational, emotional, self-esteem and social networks. Results from this research that the highest form of support in instrumental support amounted to $86.9 \%$, The second sequence that forms informational support amounted to $79.7 \%$, the third is a form of social networking support amounted to 56.5\%, in fourth form of support awards amounted to $34.8 \%$ and the fifth in the form of emotional support amounted to $23.6 \%$.

Keywords: social support virtual friends, instagram, late adolescence

Kecanggihan teknologi saat ini merupakan salah satu kemajuan peradaban manusia untuk mempermudah dan mempercepat kebutuhan manusia dalam fleksibilitas berkomunikasi dengan teman, keluarga dan rekan kerja. Tidak dipungkiri teknologi berkembang di hampir semua aspek terutama dalam bidang komunikasi. Media sosial merupakan salah satu teknologi komunikasi yang bisa diakses oleh semua kalangan. Kementerian Komunikasi dan Informatika (Kemenkominfo) mengungkapkan pengguna internet di 
Indonesia mencapai 63.000.000 orang. Dari angka tersebut, $95 \%$ menggunakan internet untuk mengakses jejaring sosial (kominfo.go.id).

Media sosial adalah salah satu dari produk internet yang memudahkan manusia dalam berkomunikasi baik yang sudah mengenal maupun belum dikenal. Dengan adanya media sosial mempermudah kita dalam mengetahui apa saja yang dilakukan oleh teman kita, sedang dimana dan kabar terbaru dari keluarga kita. Media sosial yang paling sering dimainkan antara lain Menurut data dari Webershandwick, perusahaan public relations dan pemberi layanan jasa komunikasi, untuk wilayah Indonesia ada sekitar 65.000.000 pengguna Facebook aktif. Pengguna Twitter, berdasarkan data PT Bakrie Telecom, memiliki 19.500.000 pengguna di Indonesia dari total 500.000.000pengguna global. Selain Twitter, jejaring sosial lain yang dikenal di Indonesia adalah Path dengan jumlah pengguna 700.000 di Indonesia (kominfo.go.id).

Remaja sangat aktif dalam memainkan media sosial, hampir semua media sosial dimainkan untuk mendapatkan perhatian, penghargaan dan eksistensi. Namun dengan bermain aktif di media sosial tidak saja memberikan dampak positif namun negatif. Masalah yang terjadi diakibatkan oleh media sosial dan berdampak pada kepribadian remaja dapat di lihat dalam jurnal Jama Pediatrik (edition.cnn.com), dimana $23 \%$ dari remaja menyatakan bahwa mereka pernah menjadi target dari korban kekerasan melalui sosial media dan yang lainnya $15 \%$ menyatakan bahwa pernah menjadi penyumbang kekerasan terhadap orang lain di sosial media.

Akses sosial media juga dapat mengobati dari depresi, dan ketakutan. Termasuk dari hasil penelitian National Institue of Mental Health (edition.cnn.com) pada tahun 2012, dari 2.200.000 remaja atau 9,1 \% remaja U.S. berumur 12-17 tahun, paling tidak mayoritas memiliki episode depresi di tahun sebelumnya. Remaja sangat rentan sekali mengalami masalah psikososial, yakni masalah psikis atau kejiwaan yang timbul sebagai akibat terjadinya perubahan sosial (Sujudi, 2002). Survei nasional lebih dari 10.000 remaja menunjukkan bahwa 1 dari 3 remaja memiliki kriteria anxiety disorder. Diantara gelisah juga termasuk panic disorder, anxiety disorder umum, post-traumatic stress disorder dan pobia. Dan hasilnya adalah 8.300.000 dari jumlah semua remaja. Di artikel yang sama menjelaskan bahwa sosial media nomer satu adalah facebook, paling sering dikunjungi oleh remaja dan sosial media lainnya yang tumbuh dengan populer di kalangan remaja. Instagram dan snapchat termasuk urutan yang kedua dan ketiga. Dan pada tahun 2016 Instagram sendiri memiliki 22.000.000 pengguna aktif bulanan di Indonesia. Angka tersebut diyakini akan terus meningkat (CNNIndonesia.com)

Faktor-faktor kenakalan remaja menurut Santrock (1996) yaitu identitas, kontrol diri, kelas sosial ekonomi, pengaruh tempat tinggal, proses berjalannya sebuah keluarga dan teman sebaya. Faktor terakhir merupakan faktor yang besar dalam membantu remaja menghadapi problem-problemnya. Namun memiliki teman-teman sebaya yang melakukan kenakalan meningkatkan risiko remaja untuk menjadi nakal. Pada sebuah penelitian Santrock (1996) terhadap 500 pelaku kenakalan dan 500 remaja yang tidak melakukan kenakalan di Boston, ditemukan persentase kenakalan yang lebih tinggi pada remaja yang memiliki hubungan reguler dengan teman sebaya yang melakukan kenakalan. 
Banyak sekali pengaruh yang diberikan oleh media sosial terhadap remaja. Remaja adalah usia yang menurut Hurlock (1998) merupakan masa dimana seorang individu mengalami peralihan dari satu tahap ke tahap berikutnya dan mengalami perubahan baik emosi, tubuh, minat, pola perilaku, dan juga penuh dengan masalah-masalah. Sehingga di usia remaja emosi masih sangat labil dan butuh pengarahan dan wawasan dalam bertindak. Masalah umum yang dihadapi oleh remaja adalah emosi. Sedangkan di dalam kehidupan sehari-hari emosi memegang peranan yang cukup besar.

Hessler dan Katz (2010) menyatakan hasil penelitiannya bahwa remaja memiliki ketidakstabilan emosi seperti kompetensi emosional, pengaturan emosional dan terutama regulasi emosi. Remaja membutuhkan bimbingan untuk mematangkan emosinya, dan di usia remaja rentang sekali untuk melakukan kenakalan remaja. Seperti contoh mengkonsumsi narkoba, minuman beralkohol, seks bebas, dan melakukan hal-hal yang tidak patut dilakukan. Di dalam penelitian ini dinyatakan bahwa kenalakan remaja sangat berkaitan erat dengan emosi. Jika remaja kurang baik dalam meregulasi emosi maka kemungkinan besar untuk melakukan kenakalan remaja akan semakin besar.

Ahn (2011) mengatakan bahwa efek dari situs internet memberikan efek yang positif dan negatif. Berbagai situs internet yang tersaji memiliki efek yang berbeda-beda. Namun jika remaja dapat memilah mana saja yang pantas bagi dirinya untuk membuka seperti situs internet untuk mencari pengetahuan, informasi, membantu mengerjakan tugas maka hal tersebut dapat memberikan efek yang positif bagi remaja. Hal sebaliknya jika remaja membuka situs internet yang tidak baik seperti game online maka akan berefek negatif bagi remaja.

Selain itu rentang waktu penggunaan juga haruslah terkontrol sehingga tidak menyebabkan kecanduan. Kenakalan remaja saat ini tidak hanya berasal dari rumah atau sekolah melainkan bisa berasal dari sosial media. Banyak kasus di Indonesia tentang kekerasan dan kejahatan seksual pada remaja yang baik pelaku maupun korbannya adalah remaja akibat ekspose terhadap situs-situs internet yang tidak dikontrol oleh orangtua maupun orang dewasa lain yang bertanggung jawab terhadap perkembangan remaja di Indonesia.

Budhyati (2012) disimpulkan bahwa perilaku kenakalan pada remaja yang dipengaruhi oleh media internet antara lain adalah: (a) Perkelahian sebagai akibat dari kecanduan game online yang bertema kekerasan, peperangan, terorisme; (b) Perkataan yang kotor, kasar, tidak senonoh, saling mengejek antar teman yang bermula dari penulisan "status" di facebook atau twitter dan jejaring sosial lainnya; (c) Penipuan, melalui media internet rentan sekali penipuan dengan memasang iklan-iklan jual beli barang dengan harga murah; (d) Pemalsuan identitas, melalui jejaring sosial seperti facebook, twitter, friendster dan lain-lain dengan menemukan teman yang baru dikenalnya sehingga memudahkan untuk menipu dan dapat menghindar dari tanggung jawab jika melakukan tindakan merugikan orang lain; (e) Penculikan, seringkali terjadi penculikan gadis remaja karena berkenalan dengan temannya di facebook untuk bertemu di dunia nyata sehingga membawa kabur gadis remaja tersebut; (f) Perbuatan asusila, seperti perkosaan, 
pencabulan, sex bebas, sebagai akibat dari melihat gambar/ video porno di internet; $(\mathrm{g})$ Membolos sekolah, karena begadang kecanduan game online sampai larut malam bahkan sampai pagi; (h) Berbohong pada orang tua, karena kecanduan internet membutuhkan biaya untuk ke warnet atau membeli pulsa modem.

Dukungan teman sebaya juga mempengaruhi para remaja yang lebih banyak menghabiskan waktu bersama dengan teman di sekolah. Tidak dipungkiri rasa ingin dihargai dan eksistensi sangat tinggi pada usia remaja. Terutama di media sosial yang kini menjadi salah satu alat ukur bagi remaja apakah eksistensi nya tinggi. Padahal hal ini tidak berkaitan satu sama lain. Ahn (2012) menyatakan bahwa banyak murid yang menghubungkan antara situs jaringan sosial (SNS) dan strata sosial. Hasil dari penelitian ini menyatakan bahwa remaja yang menggunakan facebook dan myspace memiliki strata sosial yang tinggi baik di dalam sekolah maupun di dunia maya dikarenakan memiliki pengikut dan jumlah suka pada akun media sosialnya tinggi. Apa yang diimaksud strata sosial ini adalah kedudukan sosial didalam pertemanan. Remaja yang menggunakan SNS merupakan jembatan untuk bisa eksis dan diharapkan memiliki keterikatan sosial dengan teman yang lain. Waktu yang dihabiskan di SNS berhubungan dengan keterikatan sosial, baik negatif maupun positif. Hal ini sama halnya seperti facebook dan myspace. Penelitian ini juga menunjukkan pemikiran baru mengenai pengalaman remaja yang menggunakan SNS dan hubungan antara pengalaman mereka dengan koneksi terhadap dunia.

Pengaruh kuat yang diberikan oleh media sosial terhadap remaja sama halnya seperti memberikan pengaruh yang kuat dalam membentuk kepribadian remaja. Dimanapun remaja berada maka media sosial akan terus bersamanya, dan hal ini juga berdampak terhadap cara remaja dalam membentuk masa depannya. Seperti contoh remaja di Bangladesh yang juga selalu memainkan media sosial sebagai tanda bahwa mereka termasuk remaja yang tidak ketinggalan jaman (Jubayer, 2013). Mereka menerima bahwa teknologi saat ini sudah menjadi bagian yang normal dari kebanyakan kehidupan remaja di Bangladesh. Meskipun begitu, remaja harus memiliki ketegasan dalam memakai media sosial, sehingga tidak melupakan tugas utama sebagai pelajar yaitu belajar untuk mencapai masa depan yang baik.

Bhargava dan Rani (2015) mengatakan bahwa pertumbuhan situs media sosial menunjukkan betapa perubahan penting sedang terjadi di kebiasaan remaja dan murid India di kehidupan mereka. Situs media sosial menjadi salah satu hal terpenting di kehidupan sekarang. Namun hal ini bisa memberikan dampak yang buruk, dapat berdampak terhadap masa depan remaja karena menghabiskan banyak waktu yang tidak penting. Selain ketergantungan juga membentuk pola pemikiran yang tidak teratur dan tidak terarah jika tidak didampingi oleh keluarga. Selain ini pergaulan terhadap teman juga akan berbeda karena terlalu senang bermain media sosial.

Teman virtual muncul seiring dengan berkomunikasi melalui media sosial. Kelebihan dari teman virtual yaitu mempermudah dalam berkomunikasi tanpa melewati kemacetan, penghematan waktu, biaya perjalanan atau cuaca yang tidak menentu. Namun kekurangan dari komunikasi secara virtual terdapat cyber bullying, cyberporn, 
cyberspace hingga terlalu berlebihan dalam menggunakan media sosial yang menimbulkan kecanduan tinggi dan tidak menghiraukan di dunia nyata. Berbanding terbalik jika berkomunikasi secara interpersonal yaitu dapat memiliki feedback baik secara dukungan maupun emosional, terdapat kedekatan emosional, dapat mengetahui jujur atau tidak dan lebih fokus. Namun terdapat kekurangan yaitu mengenai efisiensi waktu serta tidak dapat berkomuniasi dengan seseorang yang berbeda tempat (psikologizone.com).

Penelusuran yang telah dilakukan peneliti mengenai penelitian tentang teman virtual masih terbatas. Berbanding terbalik dengan dukungan sosial yang banyak sekali yang membahas. Fenomena yang terjadi saat ini pada remaja akhir adalah media sosial yang semakin maju dan canggih dan menjadi kebutuhan yang tidak bisa terlepaskan dari kehidupan sehari-hari. Termasuk teman virtual yang kini didapatkan dari media sosial. Sehingga originalitas dari penelitian ini mengenai dukungan sosial teman virtual melalui media instagram menjadi pembaruan didalam penelitian saat ini.

Berdasarkan uraian di atas tujuan penelitian ini yaitu menggambarkan dukungan sosial apa saja yang diterima dari teman virtual melalui instagram. Manfaat dari penelitian ini yaitu menambah kajian teoritis dalam bidang psikologi mengenai dukungan sosial teman virtual melalui instagram pada remaja akhir. Secara praktik dapat mengetahui positif dan negatif dalam menghabiskan waktu menggunakan instagram sebagai media sosial sebagai dukungan sosial di dunia maya. Serta sebagai sarana dalam saling mendukung antar teman di instagram dalam hal yang positif.

\section{METODE}

Rancangan penelitian ini menggunakan metode deskriptif kuantitatif. Menurut Sugiyono (2003) menjelaskan penelitian kuantitatif adalah penelitian dengan memperoleh data yang berbentuk angka atau data kuantitatif yang diangkakan. Subjek dari penelitian ini dipilih secara purposive sampling. Winarnu (2007) menyatakan bahwa purposive sampling dikenakan pada sampel yang karakteristiknya sudah ditentukan dan diketahui lebih dulu berdasarkan ciri dan sifat populasinya. Jumlah mahasiswa yang ada di UMM berjumlah 28.107 orang. Dalam tabel penentuan jumlah sampel dari populasi tertentu dengan taraf kesalahan $5 \%$ yang dikembangkan Isaac dan Michael (Sugiyono,2012) minimal subjek berjumlah 346 orang. Jumlah subjek penelitian berjumlah 428 mahasiswa UMM. Adapun karakteristik yang ditentukan adalah berumur 18-22 tahun atau setara dengan pendidikan perguruan tinggi dan pengguna instagram aktif setiap hari.

Variabel pada penelitian ini adalah dukungan sosial teman virtual melalui media instagram. Teman virtual adalah sebutan nama dari teman di dunia maya. Dunia maya sendiri dapat berkomuniksi satu sama lain ttanpa bertatap muka. Sehingga teman virtual merupakan teman yang berasal dari dunia maya tanpa berinteraksi secara intepersonal (bertatap muka) namun dikatakan teman karena dapat berkomunkasi satu dengan yang lain. 
Dukungan sosial merupakan bantuan atau tindakan yang didapatkan dari orang lain yang mempunyai manfaat emosional atau efek perilaku dari pihak penerima. Sedangkan media instagram merupakan media sosial yang digunakan sebagai fasilitas dalam berkomunikasi. Sehingga dukungan sosial teman virtual melalui media instagram yaitu dukungan sosial yang mempunyai arti tersendiri bagi penerima berupa pemberian informasi, bantuan tingkah laku, materi hingga emosional yang didapat dari interaksi sosial dari teman virtual melalui media instagram sebagai perantara untuk berkomunikasi dan membuat penerima merasa diperhatikan, dicintai dan bernilai.

Instrumen penelitian ini menggunakan kuisoner. Pengukuran ini dilakukan dengan kuisoner yang telah diuji melalui professional judgment. Adapun kuisoner dukungan sosial dibuat oleh peneliti yang mengacu pada bentuk dukungan sosial Sheridan dan Radmacher (1992). Bentuk-bentuk dukungan sosial antara lain dukungan emosional, dukungan penghargaan, dukungan instrumental, dukungan informasi dan dukungan jaringan sosial.

Analisis data meggunakan analisa statistik deskriptif dengan menggunakan analisis frekuensi. Winarnu (2007) yaitu bagian dari statistik yang membahas mengenai penyusunan data kedalam daftar, grafik, atau bentuk lain yang sama sekali tidak menyangkut penarikan kesimpulan yang dibantu menggunakan bantuan program statistik spss 21.

\section{HASIL}

Responden dalam penelitian ini adalah remaja akhir yang memiliki status mahasiswa Universitas Muhammadiyah Malang dengan rentang usia 18-22 tahun. Total subjek dalam penelitian ini adalah 428 orang. Berikut adalah penjelasan mengenai gambaran umum mengenai responden jika dilihat dari usia dan jenis kelamin.

Tabel 1.

Gambaran Umum Subjek

\begin{tabular}{lrrr}
\hline \multicolumn{1}{c}{ Klasifikasi } & F & \multicolumn{2}{c}{$\%$} \\
\hline Usia & & & \\
& 18 Tahun & 88 & $20,6 \%$ \\
19 Tahun & 57 & $13,3 \%$ \\
20 Tahun & 40 & $9,3 \%$ \\
21 Tahun & 107 & $25 \%$ \\
22 Tahun & 136 & $31,8 \%$ \\
Jenis Kelamin & & \\
Laki-laki & 121 & $28,3 \%$ \\
Perempuan & 307 & $71,7 \%$ \\
\hline
\end{tabular}


Tabel 1 menunjukkan bahwa responden paling banyak berusia 22 tahun dan 21 tahun, Sedangkan dari semua responden ternyata didominasi oleh perempuan dengan jumlah 307 orang dari 428 orang,

Tabel 2.

Gambaran secara umum dukungan instrumental

\begin{tabular}{lcccccc}
\hline \multirow{2}{*}{ Klasifikasi } & \multicolumn{2}{c}{ Bantuan Sosial } & \multicolumn{3}{c}{ Rekomendasi Kenalan } & \multicolumn{2}{c}{$\begin{array}{c}\text { Informasi Kehilangan } \\
\text { barang }\end{array}$} \\
& F & \% & F & \% & F & \% \\
\hline $\begin{array}{l}\text { Pernah } \\
\text { Tidak }\end{array}$ & 246 & $57,5 \%$ & 372 & $86,9 \%$ & 169 & $39,5 \%$ \\
pernah & 182 & $42,5 \%$ & 56 & $13,1 \%$ & 259 & $60,5 \%$ \\
\hline
\end{tabular}

Tabel 2 menunjukkan bahwa responden pernah menerima bantuan berupa rekomendasi kenalan seperti online shop, akun dokter gigi, perawatan wajah dan lain-lain denan jumlah 372 orang atau 86, $9 \%$. Dan responden tidak pernah menerima bantuan berupa membantu menyebarkan informasi kehilangan barang responden seperti kehilangan stnk, hp, uang, motor dan lain-lain dengan jumlah 259 orang atau $60,5 \%$.

Tabel 3.

Gambaran secara umum dukungan informasional

\begin{tabular}{|c|c|c|c|c|}
\hline \multirow[t]{2}{*}{ Klasifikasi } & \multicolumn{2}{|c|}{$\begin{array}{c}\text { Mendapatkan saran terkait } \\
\text { masalah personal }\end{array}$} & \multicolumn{2}{|c|}{$\begin{array}{c}\text { Mendapatkan informasi tips } \\
\text { mengenai masalah umum }\end{array}$} \\
\hline & $\mathbf{F}$ & $\%$ & $\mathbf{F}$ & $\%$ \\
\hline Pernah & 240 & $56,1 \%$ & 341 & $79,7 \%$ \\
\hline Tidak Pernah & 188 & $43,9 \%$ & 87 & $20,3 \%$ \\
\hline
\end{tabular}

Dua soal diatas sama-sama bertujuan untuk menyelesaikan masalah. Dari data yang didapat, responden lebih cenderung menerima informasi dalam menyeleseikan masalahnya seperti mendapatkan tips move on, tips merawat rambut, tips memilih hp dan lain-lain dengan jumlah 341 orang atau 79,7\%. Dan responden paling tinggi pilihanya dalam tidak pernah melakukan yaitu bercerita dan diberi saran untuk menyeleseikan masalahnya berjumlah 188 orang dari pada yang menerima informasi untuk menyeleseikan masalah dengan jumlah $20,3 \%$. 
Tabel 4.

Gambaran secara umum dukungan emosional

Klasifikasi

F

Interaksi yang diinginkan responden agar merasa dihargai dan disukai

Ditanya keadaannya

$286 \quad 66,8 \%$

Menerima nasihat

$43 \quad 10 \%$

Tidak ada yang menanyakan kabar

$34 \quad 7,9 \%$

Dikirim video lucu

$30 \quad 7 \%$

Biasa saja

$2 \quad 0,5 \%$

Ingin tahu saja tetapi tidak peduli

$3 \quad 0,7 \%$

Di-bully

$20,5 \%$

Tidak ada yang memberi respon

$3 \quad 0,7 \%$

Di-like

$1 \quad 0,2 \%$

Tidak menunjukkan kesedihan di-instagram

$18 \quad 4,4 \%$

Semua benar

$20,5 \%$

Menutup diri dari media sosial

$10,2 \%$

Kadang ada yang respon ada yang tidak

$1 \quad 0,2 \%$

Tergantung teman dan kondisinya

$1 \quad 0,2 \%$

Ditanya keadaan dan diberi nasihat

$1 \quad 0,2 \%$

\section{Respon yang paling disukai responden saat badmood}

Diberi tanda like dan komen pada foto

Dilihat dan diberi komentar di instastory

$94 \quad 22,1 \%$

Dihibur dengan menerima video lucu

$101 \quad 23,6 \%$

Dichatting melalui DM

$137 \quad 32 \%$

Semua benar

Belum pernah menunjukkan bad mood di instagram

Diam saja

$6 \quad 1,4 \%$

Di-bully

2

$0,5 \%$

Menjadi lebih semangat

$1 \quad 0,2 \%$

Dihibur

$10,2 \%$

$10,2 \%$

Tidak memainkan instagram

$6 \quad 1,4 \%$

Ditlaktir makan

$1 \quad 0,2 \%$

Tidak ada pengalaman mengenai hal ini

$2 \quad 0,5 \%$ 
Klasifikasi

Perasaan responden setelah menerima respon yang disukai

Senang dan merasa dipedulikan

165

$13230,8 \%$

Dihibur sehingga membuat lebih tenang

Merasa mendapatkan semangat baru

Biasa saja

Semua benar

Tidak ada komentar

Belum pernah curhat di instagram

Apakah responden pernah menerima dukungan dan semangat

Pernah

Tidak pernah

\section{Sering memberikan interaksi terhadap responden}

Teman yang dikenal

Teman yang tidak dikenal

Responden menyatakan bahwa saat menunjukkan kesedihannya di media instagram, respon yang paling tinggi didapat yaitu menanyakan keadaan dengan jumlah 286 orang atau $66,8 \%$, Dan hal ini sesuai dengan respon yang paling disukai responden pada saat bad mood yaitu chattingan melalui DM dengan jumlah tertinggi yaitu 137 orang atau 32 $\%$ karena menanyakan keadaan di media instagram secara pribadi yaitu melalui media DM.

Perasaan yang dirasakan oleh responden setelah menerima respon yang disukai yaitu merasa senang dan merasa diperdulikan dengan jumlah 165 orang atau 38,6\%. Selain itu responden menyatakan pernah menerima dukungan dan semangat dari teman virtual di media instagram agar dapat menyeleseikan masalah dengan jumlah 362 orang atau $84,6 \%$. Responden juga merasa mendapatkan banyak interaksi dari teman yang dikenal di media instagram dengan jumlah 99,5\% atau sebanyak 426 orang. Namun, ada juga responden yang menyatakn tidak menunjukkan rasa kesedihannya di media instagram dengan jumlah 18 orang atau 4,3\%. Didukung dengan data selanjutnya yang menyatakan pada saat badmood responden memilih tidak memainkan media instagram berjumlah 6 orang, tidak menunjukkan rasa badmood 6 orang. 
Tabel 5.

Gambaran secara umum dukungan penghargaan

\begin{tabular}{lrr}
\hline \multicolumn{1}{c}{ Klasifikasi } & F & \multicolumn{1}{c}{$\%$} \\
\hline Interaksi yang diinginkan responden agar merasa dihargai dan disukai & \\
\hline Foto diberi like dan komen & 114 & $26,6 \%$ \\
Instastory dilihat dan diberi komen & 7 & $1,6 \%$ \\
Ditanya kabar melalui chatting DM & 44 & $10,3 \%$ \\
Semua benar & 227 & $53 \%$ \\
Biasa saja & 10 & $2,4 \%$ \\
Komentar yang diberikan dibalas & 1 & $0,2 \%$ \\
Memberi komentar secara pribadi melalui DM & 3 & $0,7 \%$ \\
Memperbanyak teman di dunia nyata & 1 & $0,2 \%$ \\
Di-follow saja & 5 & $1,3 \%$ \\
Tidak di-bully & 2 & $0,5 \%$ \\
Dapat memberikan inspirasi & 4 & $1 \%$ \\
Disukai karena jadi diri sendiri & 1 & $0,2 \%$ \\
Menggunakan instagram sewajarnya & 2 & $0,5 \%$ \\
Tidak spam & 1 & $0,2 \%$ \\
Tidak begitu butuh perhatian dari sosial media & 3 & $0,7 \%$ \\
Mementingkan informasi dari dunia luar & 1 & $0,2 \%$ \\
Instagram hanya menumbuhkan kepalsuan saja, sehingga sosmed & & \\
bukan jalan yang benar untuk saling menghargai & 1 & $0,2 \%$ \\
Menulis di instagram tidak untuk orang lain, melainkan sebagai & & \\
pengingat diri sendiri & 1 & $0,2 \%$
\end{tabular}

Interaksi yang sering diterima responden sehingga merasa dihargai secara positif

Diberi tanda like pada foto

Diberi komentar pujian terhadap foto diri anda $\quad 67 \quad 15,7 \%$

Ditag foto bersama teman-teman $\quad 136 \quad 31,8 \%$

$\begin{array}{lrr}\text { Instastory dilihat terus dan diberi komentar } & 56 & 13,1 \%\end{array}$

Interaksi yang sering diterima responden sehingga merasa dihargai secara positif

Biasa saja

$8 \quad 1,9 \%$

Tidak dicela

$2 \quad 0,5 \%$

$\begin{array}{lll}\text { Komentar yang diberikan dibalas } & 1 & 0,2 \%\end{array}$

$\begin{array}{lll}\text { Ditanya kabar } & 2 & 0,5 \%\end{array}$

Semua benar $\quad 5 \quad 1,3 \%$

Diberi semangat $\quad \begin{array}{ll}1 & 0,2 \%\end{array}$

$\begin{array}{lll}\text { Tidak megnharapkan penghargaan dari instagram } & 1 & 0,2 \%\end{array}$

\begin{tabular}{lll} 
Benar semua kecuali yang diberi pujian & 1 & $0,2 \%$ \\
\hline
\end{tabular}

Berdasarkan tabel 5, responden ingin mendapatkan interaksi berupa foto responden di like dan dikomen, instastory responden dilihat dan dikomen teman virtual, ditanya kabar dan dichatting melalui DM agar merasa dihargai dan disukai dengan jumlah $53 \%$. Sedangkan interaksi yang didapat oleh responden dengan nilai tertinggi yaitu diberi tanda like pada foto responden dengan jumlah $34,6 \%$. 
Hal ini sesuai dengan interaksi yang diharapkan respon yaitu foto di like dan dikomen dengan jumlah 25,9\%. Selain itu dengan difollow saja oleh teman virtual, responden merasa dihargai dan disukai dengan jumlah 5 orang atau 1,3\%. Bahkan responden merasa biasa saja ketika menerima interaksi dari teman virtual dengan jumlah 8 orang atau $1,9 \%$.

Tabel 6.

Gambaran secara umum pertemanan di Instagram

\begin{tabular}{|c|c|c|c|c|c|c|}
\hline \multirow[t]{2}{*}{ Klasifikasi } & \multicolumn{2}{|c|}{$\begin{array}{l}\text { Di-follow teman yang } \\
\text { kenal }\end{array}$} & \multicolumn{2}{|c|}{$\begin{array}{l}\text { Di-follow teman yang } \\
\text { tidak dikenal }\end{array}$} & \multicolumn{2}{|c|}{$\begin{array}{c}\text { Merasa didukung } \\
\text { karena di-follow }\end{array}$} \\
\hline & $\mathbf{F}$ & $\%$ & $\mathbf{F}$ & $\%$ & $\mathbf{F}$ & $\%$ \\
\hline & $\overline{398}$ & $\overline{93}$ & 400 & $93,5 \%$ & 364 & $85 \%$ \\
\hline dak & 30 & $17 \%$ & 66 & $6,5 \%$ & 64 & $15 \%$ \\
\hline
\end{tabular}

Dapat dilihat pada tabel 6,93\% responden mengaku bahwa difollow oleh teman yang dikenal dan 93,5\% responden juga difollow oleh teman yang tidak dikenal. Dan responden sendiri merasa didukung dengan difollow oleh teman yang dikenal maupun yang tidak dikenal dengan jumlah $85 \%$.

Tabel 7.

Gambaran secara umum dukungan jaringan sosial

\begin{tabular}{lrr}
\hline \multicolumn{1}{c}{ Klasifikasi } & F & \% \\
\hline Memfollow akun artis, akun komunitas & 401 & $93,7 \%$ \\
Iya & 27 & $6,3 \%$ \\
Tidak & & \\
Alasan memfollow akun-akun kelompok tersebut & 242 & $56,5 \%$ \\
$\begin{array}{l}\text { Dijadikan refrensi untuk mendapatkan ide } \\
\text { Dapat memacu semangat untuk berkarya }\end{array}$ & 59 & $13,8 \%$ \\
Menerima berita dan informasi terbaru mengenai idola & 101 & $23,6 \%$ \\
Sebagai bentuk dukungan terhadap idolanya & 6 & $1,4 \%$ \\
Sebagai hiburan & 2 & $0,5 \%$ \\
Idola sebagai inspirasi & 4 & $1 \%$ \\
Alasan memfollow akun-akun kelompok tersebut & & \\
Mendapatkan informasi pengetahuan & 3 & $0,7 \%$ \\
Tidak follow akun-akun tersebut & 1 & $0,2 \%$ \\
Hobi saja & 1 & $0,2 \%$ \\
Semua benar & 7 & $1,7 \%$ \\
$\begin{array}{l}\text { Dirasa dapat memacu semangat dan menerima berita } \\
\text { tentang idola }\end{array}$ & 1 & $0,2 \%$ \\
Hanya sekedar tau saja & 1 & $0,2 \%$ \\
\hline
\end{tabular}

Tabel 7 menggambarkan bahwa responden memfollow akun artis, akun komunitas yang sesuai dengan minatnya, tutorial make up dan lain lain dengan jumlah 93, $7 \%$. Alasan terbesar yang dipilih responden memfollow akun-akun tersebut yaitu sebagai refensi untuk mendapatkan ide dengan jumlah $56,5 \%$ dan alasan terbesar yang kedua adalah untuk mendapatkan berita dan informasi terbaru dari akun tersebut dengan jumlah $23,6 \%$. 
Tabel 8.

Gambaran umum mengenai data tambahan

\begin{tabular}{lrl}
\hline \multicolumn{1}{c}{ Klasifikasi } & F & \% \\
\hline Respon yang diterima dari teman yang dikenal dan yang tidak dikenal & \\
Diberi like dan diberi komen pujian pada fotonya & 354 & $82,7 \%$ \\
Dilihat Instastory dan dikomen & 267 & $62,4 \%$ \\
Ditanya keadaan dan di chatting melalui DM & 228 & $52,3 \%$ \\
Dilihat dan dikomen pada saat live di instagram & 103 & $24,1 \%$ \\
Menerima nasehat dan didukung saat bad mood & 169 & $39,5 \%$
\end{tabular}

Respon yang diterima dari teman yang dikenal dan yang tidak dikenal

Dihibur dengan menerima video lucu

$16939,5 \%$

Ditag oleh teman-teman baik di instastory ataupun di foto

Respon ada yang negatif dan positif

$10,2 \%$

Semua benar

$6 \quad 1,4 \%$

Banyak cara

$10,2 \%$

Diam saja

$1 \quad 0,2 \%$

Respon yang diterima dari teman yang dikenal dan yang tidak dikenal

Foto hanya dilike saja

Dikomen aja cukup

Manfaat yang diterima setelah menggunakan instagram

Menerima berita dan informasi terbaru

$1 \quad 0,2 \%$

$10,2 \%$

Mendapatkan inspirasi untuk berkarya

403

$94 \%$

Merasa ada motivasi dan semangat baru

$68 \%$

Mudah mengetahui kabar terbaru dari teman-teman

$58,9 \%$

Merasa lebih dekat dengan teman-teman

354

$82,7 \%$

Mendapatkan dukungan menjadi lebih baik

Menerima nasehat untuk menyelesaikan masalah yang dihadapi

Waktu terasa terbuang

Mengisi kekosongan waktu

153

$35,7 \%$

Bisa mendapatkan pacar

$10,2 \%$

$2 \quad 0,4 \%$

Melihat video tatan

Dampak positif dan negatif yang dirasakan

Biasa saja, sama seperti dunia nyata

$0,2 \%$

$1 \quad 0,2 \%$

Mudah mengetahui kabar terbaru dari teman

$101 \quad 23,4 \%$

$24256,6 \%$

Menyenangkan, lebih mudah mengetahui tempat baru, dan rekomendasi bagus

Mudah dalam menerima teman baru dan saling mendukung

Banyak yang ingin pamer harta dan kegiatan, biar terlihat tenar dan bersaing

Susah mengetahui karakter asli dari teman virtual, sehingga

respon yang diterima berbeda antara dunia maya dan nyata

$149 \quad 34,8 \%$

Lebih luas dalam bergaul

$10,2 \%$

Macam-macam tergantung pengguna

$0,2 \%$

Pertemanan adalah sebuah hubungan

$10,2 \%$


Pada tabel 8 responden menyatakan bahwa bentuk respon yang paling sering diterima baik dari teman yang dikenal maupun tidak dikenal yaitu menerima tanda like dan komen berisi pujian terhadap foto yang diupload. Urutan yang kedua yaitu dilihat dan diberi komen terhadap instastory nya. Urutan yang ketiga yaitu ditag oleh teman-teman baik di foto maupun di instastory. Responden merasa semua pilihan jawaban benar berjumlah 6 orang atau $1,4 \%$.

Manfaat yang dirasa oleh responden yaitu mendapatkan informasi dan berita terbaru dengan jumlah 403 orang atau 94\%, urutan kedua yaitu mudah mengetahui kabar terbaru dari teman-teman dengan jumlah 354 orang atau 82,7\%, dan urutan ketiga mudah mendapatkan inspirasi untuk berkarya dengan jumlah 291 orang atau $68 \%$. Meskipun begitu, 1 responden merasa bahwa bermain instagram hanya membuang waktu. Dampak positif dan negatif dari penggunaan instagram antara lain merasa senang, karena mudah mengetahui informasi tentang teman di instagram seperti tempat rekreasi baru, rekomendasi online shop bagus dengan jumlah 298 orang atau 69,6\%. Sedangkan dampak negatif yaitu susah untuk mengetahui karakter asli dari teman-teman virtual, sehingga respon yang diterima saat di dunia maya dengan dunia nyata berbeda dengan jumlah 149 orang atau 34,8 \%. Selain itu, teman virtual terlihat seperti bersaing karena mencari ketenaran di instagram dengan pamer harta atau kegiatan berjumlah 111 orang atau $26 \%$.

\section{DISKUSI}

Dari hasil penelitian di atas menunjukkan bahwa bentuk dukungan sosial teman virtual melalui instagram sama seperti dukungan sosial teman secara interpersonal. Bentuk dukungan sosial menurut Sheridan dan Radmacher (1992) antara lain dukungan instrumental, dukungan informasional, dukungan emosional, dukungan penghargaan dan dukungan jaringan sosial. Meskipun secara bentuk dukungan sosial sama, namun caranya yang berbeda. Bentuk dukungan sosial yang diterima responden jika dilihat dari dukungan instrumental yaitu mendapatkan bantuan secara langsung. Sedangkan bentuk dukungan instrumental melalui media instagram caranya yaitu dengan menyebarkan informasi yang penting sesuai kebutuhan responden melalui media instagram. Seperti bantuan sosial yang pernah dirasakan responden yaitu mencarikan donor darah, penggalangan dana di media instagram mencapai $57,5 \%$ dan bantuan informasi kehilangan barnag seperti menyebarluaskan berita kehilangan stnk, hingga kehilangan motor dengan mencantumkan no plat sepeda dengan jumlah 39,5\%. Sehingga saat disebarkan melalui media instagram diharapkan bantuan yang diberikan melalui media instagram lebih menjangkau banyak orang dan lebih cepat bantuan yang diterima oleh responden .

Jika di dunia nyata bentuk dukungan instrumental berupa bantuan secara materil seperti pinjaman uang, pemberian uang, makanan serta pelayanan, di dunia maya juga berupa bantuan secara materil namun cara mendapatkannya berbeda. Pada akhirnya tujuan dari dukungan instrumental yaitu mengurangi kecemasan agar individu dapat memecahkan masalahnya yang berhubungan dengan materi agar dapat tercapai. Hal ini sesuai dengan 
Smet (1994) bahwa dukungan instrumental mencakup bantuan langsung, seperti orangorang memberi pinjaman uang kepada orang itu atau menolong dengan pekerjaan pada waktu mengalami stres.

Sama halnya dengan bantuan melalui media instagram, dimana menolong dengan bantuan secara cepat dengan menyebarluaskan berita penting bertujuan agar lebih cepat menerima bantuan dan mengurangi rasa kecemasan. Bentuk dukungan instrumental lainnya yang paling sering diterima responden adalah rekomendasi kenalan mengenai kebutuhan yang dialami responden seperti online shop bagus dan terpercaya, kenalan dokter gigi, hingga rekomendasi yang lain. Rekomendasi ini pernah diterima responden hingga mencapai $86,9 \%$. Sedangkan bantuan yang jarang diterima responden adalah bantuan penyebaran informasi kehilangan barang responden seperti kehilangan stnk, hp, uang, motor dan lain-lain. Bantuan ini jarang diterima oleh responden hingga mencapai $60,5 \%$.

Secara garis besar, usia remaja akhir yaitu antara umur 18 - 22 tahun (Mappiare, 1982) merupakan masa beradaptasi dengan lingkungan baru yang beralih dari ruang lingkup sekolah menengah ke atas menuju dunia kerja orang dewasa. Masa remaja sendiri merupakan fase pencarian jati diri, dimana banyak sekali masalah yang harus segera diselesaikan dengan bijak dan tepat. Tidak heran jika remaja akhir membutuhkan dukungan teman sebaya untuk menyelesaikan masalah yang dihadapi. Namun dengan adanya sosial media yang menjadi fasilitas untuk berkomunikasi dan mempermudah responden untuk berkomunikasi dengan teman sebayanya melalui media instagram. Tidak menutup kemungkinan dengan berkomunikasi melalui media instagram dapat menerima dukungan sosial.

Bentuk dukungan informasional berjumlah 56,1\% responden pernah bercerita mengenai permasalahannya dan mendapatkan saran untuk menyelesaikan. Tidak hanya itu, responden juga mendapatkan informasi untuk menyelesaikan yang di hadapi seperti tips memilih hp, tips merawat rambut dan lain-lain dengan jumlah 79,7 \%. Sesuai dengan Apollo dan Cahyadi (2012) bahwa dukungan informatif yang dimaksud adalah berupa nasehat, sugesti, arahan langsung, dan informasi. Sama halnya dengan dunia nyata, bahwa remaja akhir bercerita tentang masalahnya kepada teman sebayanya untuk mendapatkan saran mengenai masalahnya. Tidak ada perbedaan dalam dukungan sosial dukungan informasional, hanya fasilitas yang digunakan berbeda.

Bentuk dukungan emosional yang didapat dari teman virtual dilalui dengan menunjukkan terlebih dahulu apa yang dirasakan responden di media instagram kemudian akan muncul respon dari teman virtual seperti yang diharapkan oleh responden. Sama halnya dengan teman di dunia nyata, perbedaanya adalah jika secara intepersonal maka remaja akhir akan memilih terlebih dahulu siapa teman sebaya yang kiranya akan dapat dipercaya untuk mendengarkan cerita mengenai masalah yang dihadapi responden. Berbeda dengan dunia maya, ketika responden menunjukkan masalahnya di media instagram baik melalui fitur instastory atau postingan foto maka yang mengetahui hal tersebut adalah teman virtual secara keseluruhan dan tidak semua teman virtual akan memberikan respon balik terhadap remaja akhir tersebut, sehingga hanya beberapa teman virtual yang akan 
mengetahui dan merespon balik. Namun tidak semua seperti itu, responden bisa memilih teman virtual sebagai teman yang akan diceritakan masalahnya melalui fitur DM secara private. Sehingga dukungan emosional lebih didapat dengan kehadiran teman sebaya baik secara interpersonal maupun dunia maya.

Responden menyatakan saat menunjukkan kesedihan di media instagram respon yang didapat yaitu menanyakan keadaan responden dengan jumlah 66,8 \%. Dan pada saat responden bad mood, respon yang paling disukai yaitu dengan menerima kiriman berupa video lucu dari teman virtual dengan jumlah 23, $6 \%$. Menurut Taylor, Shelley, Peplau \& Sears (2009) respon yang diberikan oleh teman virtual terhadap responden yaitu perhatian emosional yang diekspresikan melalui rasa suka, cinta atau empati, misalnya ketika dalam pertengkaran dengan seorang yang dicintai, maka ekspresi perhatian dari teman sangatlah membantu. Rasa empati dan peduli muncul dari teman virtual kepada responden yang membuat responden menjadi lebih baik. Hal ini diperkuat dengan hasil data yang menyatakan bahwa responden merasa lebih senang dan merasa dipedulikan setelah menerima respon yang disukai dengan jumlah 38,6 \%. Dan urutan kedua merasa lebih tenang karena terhibur dengan jumlah 30,8 \%. Sama halnya dengan Sarafino (2002) yang menyatakan bahwa perhatian, empati dan turut prihatin kepada seseorang membuat penerima merasa nyaman, tentram kembali, merasa dimiliki dan dicintai ketika dia mengalami stres, memberi bantuan dalam bentuk semangat, kehangatan personal dan cinta. Responden juga pernah mendapatkan dukungan dan semangat berjumlah $84,6 \%$.

Responden merasa menerima bentuk dukungan emosional lebih banyak dari teman yang kenal dengan jumlah 95,5\%. Diperkuat dengan menurut Gottlieb (1983) dukungan sosial adalah informasi verbal atau non-verbal, saran, atau tingkah laku yang diberikan oleh orang-orang yang akrab dengan subjek di dalam lingkungan sosialnya atau yang berupa kehadiran dan hal-hal yang dapat memberikan keuntungan sosialnya atau berpengaruh pada tingkah laku penerimanya. Sehingga memang dukungan sosial lebih banyak diberikan oleh orang-orang yang akrab dengan responden atau dikenal oleh responden.

Bentuk dukungan penghargaan di dunia nyata bisa berupa persetujuan terhadap pendapat remaja akhir. Seperti contoh responden memberikan sebuah pendapat dan teman sebayanya setuju dengan pendapat yang dikatakan responden. Selain itu bisa berupa penghargaan terhadap responden karena telah mengikuti lomba atau kelebihan-kelebihan responden yang diakui oleh teman sebayanya. Sedangkan di media instagram, responden merasa dihargai ketika interaksi yang inginkan didapat oleh responden dari teman virtualnya yaitu foto dilike dan dikomen, instastory dilihat dan dikomen dan menanyakan kabar dan chatting melalui DM dengan jumlah total 53\%. Bentuk lainnya yaitu konten yang diunggah oleh responden mendapatkan respon dari teman virtual. Urutan kedua yang diinginkan oleh responden adalah dengan dilike fotonya dan dikomen dengan jumlah $25,9 \%$. Sedangkan interaksi yang diterima oleh responden agar merasa dihargai secara responden yaitu dilike dan dikomen foto responden dengan jumlah 34,6\%. Hal ini sesuai dengan interaksi yang diharapkan dan interaksi yang diterima yaitu dilike dan dikomen fotonya. Interaksi ini membuat responden merasa dihargai oleh orang lain sehingga responden merasa bangga dan merasa diakui keberadaannya, selain itu juga meningkatkan rasa percaya dirinya. Menurut Prayitno (2006) kebutuhan psikologis 
remaja dengan mendapat status remaja itu membutuhkan perasaan bahwa dirinya berguna, penting, dibutuhkan orang lain atau memiliki kebanggaan terhadap dirinya sendiri.

Merasa dihargai secara positif juga dapat diterima dengan difollow oleh teman yang dikenal oleh responden dengan jumlah 93\%. Sedangkan responden juga difollow oleh orang yang tidak dikenal dengan jumlah lebih banyak 93,5\%. Sebanyak $85 \%$ responden menjawab merasa didukung karena difollow oleh teman yang dikenal maupun tidak. Sesuai dengan Sarason, Levine, Basham \& Sarason (1983) yang berpendapat bahwa dukungan sosial mencakup jumlah sumber dukungan sosial yang tersedia, hal ini merupakan persepsi individu terhadap sejumlah orang yang dapat diandalkan saat individu membutuhkan bantuan.

Bentuk dukungan jaringan sosial jika di dunia nyata dapat berupa mengikuti komunitas yang ada dilingkungan remaja akhir seperti komunitas pecinta alam, paduan suara, fotografi dan lain-lain. Sehingga ruang lingkup pergaulan luas dan memiliki teman sebaya yang banyak pula. Berbeda cara dengan dukungan jaringan sosial melalui media instagram. Responden memfollow akun-akun yang sesuai dengan minatnya seperti akun fotografer yang didalamnya memuat karya mengenai fotografer, tutorial make up, idola pesepakbola dan lain-lain. Sehingga responden mendapatkan dukungan secara internal mengenai wawasan yang sesuai dengan minatnya.

Bentuk dukungan yang didapatkan pun berbeda antara dunia maya dengan dunia nyata, secara dunia nyata ikut terlibat secara langsung didalamnya sedangkan di dunia maya responden mendapatkan dukungan berupa motivasi. Responden mengaku mengikuti akun idola atau akun-akun yang sesuai dengan minatnya seperti tutorial make up, idola pesepakbola dan lain-lain dengan jumlah 93,7\%.

Alasan responden mengikuti akun-akun tersebut yaitu sebagai referensi untuk mendapatkan ide dengan jumlah 56,5\%. Diperkuat oleh Balogun (2014) bahwa keterampilan sosial, individu dengan pergaulan yang luas akan memiliki jaringan sosial yang tinggi, sehingga akan memiliki jaringan sosial yang luas pula. Sedangkan individu yang memiliki yang memiliki jaringan sosial yang kurang luas maka akan memiliki keterampilan sosial yang rendah. Keterampilan yang tinggi tersebut dapat berasal dari memfollow akun yang diminati sehingga menumbuhkan ide untuk keterampilan yang membuat sesuatu karena terinspirasi. Hal ini diperkuat dengan Eisa, Rushud, Alghadir, Anwer, Harbi, Sughaier, Yoseef, Otaibi \& Muhaysin (2016) hasil dari penelitian menyatakan bahwa ada perbedaan motivasi terutama kelompok kontrol dalam berolahraga dirumah dengan menggunakan media instagram dan tidak. Hasilnya pun berbeda, subjek yang merupakan mahasiswa perempuan yang belum lulus menggunakan instagram ternyata lebih semangat dalam menjalankan olahraga dirumah karena terdapat refrensi melalui instagram dan hal ini efektif untuk memotivasi.

Bentuk interaksi yang paling banyak diterima oleh responden di media instagram berasal dari jenis kelamin perempuan dengan jumlah $73,4 \%$ dan interaksi yang diterima dari teman virtual perempuan antara lain foto dilike dan dikomen, instastory dilihat dan 
dikomen, menanyakan kabar dan chatting melalui DM dengan jumlah 45,6\%. Menurut Soekanto (2007), seseorang dalam memberikan reaksi atas perbuatan/tindakan orang lain, mempunyai kecenderungan untuk memberikan keserasian dengan tindakan-tindakan orang lain. Karena dua hal yaitu keinginan untuk menjadi satu bersama manusia sekelilingnya dan yang kedua ingin menyatu dengan alam.

Sama halnya dengan responden yang memberikan dukungan terhadap teman virtualnya yaitu melihat-lihat foto di instagram dengan jumlah 68,7\%. Kemudian aktivitas terbesar keduanya yatu melihat instastroy dengan jumlah $23,1 \%$. Sedangkan jumlah interaksi yang berasal dari laki-laki berjumlah $26,2 \%$. Interaksi yang dirasakan oleh responden yaitu foto responden dilike dan dikomen dengan jumlah 33,9\%. Manfaat dari dukungan sosial teman di dunia nyata sama dengan manfaat dukungan sosial teman virtual yaitu mendapatkan bantuan ketika remaja akhir membutuhkan saran, arahan, motivasi, inspirasi hingga kabar terbaru dari teman. Hal ini menunjukkan teman virtual dari responden memiliki perilaku sosial yang mana, perilaku sosial juga identik dengan reaksi seseorang terhadap orang lain (Ibrahim, 2001). Dengan memiliki perilaku sosial maka dapat mendukung satu sama lain. Dampak dari dukungan sosial teman di dunia nyata mungkin lebih sedikit daripada teman virtual. Jika di dunia nyata bisa secara interpersonal dan saling mengetahui mengenai karakter dan sifat teman sebayanya. Berbeda dengan teman virtual yang hanya mengetahui melalui foto dan chattingan yang tidak bisa mengetahui secara detail karakter dan sifat asli dari teman virtual tersebut. Sehingga untuk memuncul rasa kepercayaan sangat kecil meskipun ada peluang. Hal ini bisa saja terjadi terdapat teman virtual yang di dunia nyata tidak kenal. Berbeda jika teman virtual tersebut juga teman di dunia nyata, sehingga responden kurang lebih masih mengetahui sifat dan karakter teman sebaya tersebut.

Menjadi teman yang baik di dunia nyata maupun di dunia maya bisa dilakukan. Survei yang dilakukan oleh Hollander (2010) mengunjungi teman facebook yang berjumlah 626 orang dengan 4 benua, 12 negara, 43 negara bagian Amerika Serikat. Ia disambut lebih dari 400 rumah dan menemukan bahwa tidak ada perbedaan antara pertemanan dunia maya dan di dunia nyata. Menurut Monks (2009) mengemukakan bahwa interaksi dengan teman sebaya merupakan permulaan hubungan persahabatan. Hubungan ini memiliki sifat-sifat yaitu saling pengertian, saling membantu, saling percaya, saling menghargai dan menerima. Sehingga responden merasa mengetahui teman virtualnya memiliki karakter yang sama dengan di dunia nyata untuk memunculkan rasa saling percaya agar bisa menjadi teman yang baik.

Teman virtual banyak yang memamerkan harta atau kegiatan untuk mencari ketenaran dan followers di media instagram agar mendapatkan pengakuan dari teman virtual lainnya. Dan terlihat teman virtual satu dengan lainnya sedang bersaing. Responden yang melihat berulang kali hal ini dapat mempengaruhi cara berfikir dan kebiasaan di dunia nyata. Maier, Laumer, Eckhardt \& Weitzel (2015) dalam penelitiannya mewawancarai 12 orang dan survey terhadap 571 user facebook. Hal yang didapat yaitu subjek yang terlalu banyak memperhatikan teman-teman virtualnya akhirnya mempengaruhi kehidupan secara pribadi, sehingga hal ini membuat subjek haus akan rasa penasaran dan ini menjadi perhatian khusus untuk membatasi pemakaian sosial media. 


\section{SIMPULAN DAN IMPLIKASI}

Berdasarkan hasil penelitian ini, dapat disimpulkan bahwa bntuk dukungan yang didapat melalui media instagram berdasarkan dengan jumlah tertinggi yaitu bentuk dukungan instrumental yaitu mendapatkan rekomendasi kenalan dengan jumlah 372 orang $(86,9 \%)$ diurutan yang kedua bentuk dukungan informasional yaitu mendapatkan informasi tips mengenai masalah umum dengan jumlah 341 orang $(79,7 \%)$. Urutan yang ketiga bentuk dukungan jaringan sosial yaitu dijadikan refrensi untuk mendapatkan ide dengan jumlah 242 orang $(56,5 \%)$. Urutan keempat yaitu bentuk dukunganpenghargaan dengan diberi tanda like pada foto dengan jumlah 148 orang $(34,8 \%)$ dan urutan yang kelima bentuk dukungan emosional yaitu dihibur dengan menerima video lucu berjumlah 101 orang $(23,6 \%)$. Manfaat yang diterima setelah menggunakan isntagram dengan jumlah tertinggi yaitu mudah mengetahui kabar terbaru dari teman dengan jumlah 354 orang $(58,9 \%)$. Dampak positif yang dirasakan yaitu merasa senang dan lebih mudah mengetahui tempat terbaru dan rekomendasi bagus dari teman virtual dengan jumlah 298 orang $(69,6 \%)$ dan dampak negatif yang dirasakan yaitu susah mengetahui karakter asli dari teman virtual, sehingga respon yang diterima berbeda antara dunia maya dan nyata dengan jumlah 149 orang $(34,8 \%)$.

\section{REFERENSI}

Ahn, J. (2011). The Effect of Social Network Sites on Adolescents' Social and Academic Development: Current Theories and Controversies. Journal Of The Americn Society For Information Science And Technology 62(8):1435-1445.

Apollo, \& Cahyadi, A. (2012). Konflik Peran Ganda Perempuan Menikah yang Bekerja Ditinjau dari Dukungan Sosial Keluarga dan Penyesuaian Diri.Jurnal Widya Warta, 02, 255-271.

Balogun, A. G. (2014). Dispotional Factors, Perceived Social Support and Happiness Among Prison Inmates in Nigeria : A new look. The Journal of Happiness \& Well-Being. 2, (1): 16-33.

Bhargava, A., \& Rani, M. (2015). The Influence Of Social Media On indian Teenagers. International Journal of Science, Technology \& Management 04, (1).

Budhyati, A. (2012) . Pengaruh Internet Terhadap Kenakalan Remaja. Prosiding Seminar Nasional Aplikasi Sains \& Teknologi ( SNAST). Periode III.

Camara, M., Bacigaupe, G. \& Padilla, P. (2013). The role of social support in adolescents : are you helping me or stressing me out ?. Department of Psychology and Education, University of Deusto, Bilbao, Spain.

Colarossi, $\quad$ L. G. (2001). Adolescent gender differences in social support : 
Structure, function, and provider type. Soc Work Res. 25 (4): 233-241.

Eisa, E., Rushud, A., Alghadir, A., Anwer, S., Harbi, B., Sughaier, N., Yoseef, N. Otaibi. R. \& Muhaysin, H. (2016). Effect of Motivation by (Instagram) on Adherence to Physical Activity among Female College Students. BioMed Research International.

Gottlieb, B. H. (1983). Social Support Strategies, Guidelines for Mental Health Practice. London : Sage Publications.

Hollander, T. (2010). Wanita Ini Kujungi 626 Teman Facebookya di 43 Negara. Diakses pada tanggal 19 Juli, 2017, dari http://www.citizen6.liputan6.com/read/2993327/wanita-ini-kunjungi-626-temanfacebooknya-di-43-negara.

Hostinar, C. E. (2013). Social support as buffer against stress in early adolescence: What support sources are most important to children, and do those sources change as youth navigate the transition to adolescence? (http://www.apa.org/pi/families/resources/newsletter/2014/12/stress-earlyadolescence.aspx pada tanggal 7 April 2017)

Hurlock, E. B. (1998) .Perkembangan Anak. Jakarta: Erlangga.

Hessler, D. M., \& Katz, L. F. (2010). Associations between emotional competence and adolescent risky behavior. Journal of Adolescence 33 (2010) 241-246.

Ibrahim, R. (2001). Landasan Psikologis Pendidikan Jasmani di Sekolah Dasar. Departemen Pendidikan Nasional. Dirjen Pendidikan Dasar dan Menengah Tahun 2000 .

Jubayer, Al. (2013). The Use of Social Networking Sites Among Teenagers: A Study of Facebook Use in Dhaka City. University of Dhaka. Journal of International Social Issues 2, (1): 35-44.

Maier, C., Laumer, S., Eckhardt, A. \& Weitzel, T. (2015). Giving Too Much Social Support: Social Overload On Social Networking Sites. European Journal of Information Systems.

Mappiare. A. (1982) . Psikologi Remaja. Surabaya: Usaha Nasional.

Monks. (2009). Tahap Perkembangan Masa Remaja. Medical Journal New Jersey Muagman, 1980. Defenisi Remaja. Jakarta : Penerbit Grafindo Jakarta.

Papalia, D. E., Old, S. W., \& Feldman, R. D. (2008). Human Development (Psikologi Perkembangan). Jakarta: Kencana. 
Prayitno, E. (1989). Motivasi Dalam Belajar dan Berprestasi. Jakarta: Departemen Pendidikan dan Kebudayaan Direktorat Jenderal Pendidikan Tinggi.

Santrock, J.W. (1996). Adolescence. (6th Edition). Dubuque, Lowa : Wm. C.

Brown Publishers.

Sarafino, E. P,. (2002) . Health Psychology Biopsychological Interaction. 2nd ed.New John Wiley and Sons Inc.

Sarason, I.G., Levine, H.M., Basham, R.B \& Sarason, B.R. (1983) Assesing Social Support : The Social Support Questionaire. Journal of Personality and Social Psychology.

Sheridan, D \& Radmacher, A. (1992). Personal and Contextual Determinant Strategies. Journal of personality and Social Psychology 52: 945-955. Smet, B. (1994). Psikologi Kesehatan. PT. Gramedia Widiasarana Indonesia.

Sugiyono. (2003). Metode Penelitian Bisnis. Bandung : Alfabeta.

Sugiyono. (2012). Memahami Penelitian Kualitatif. Bandung : Alfabeta.

Sujudi. (2002). Mikrobiologi Kedokteran. Jakarta: Bina Rupa Aksara.

Soekanto, S. (2007). Sosiologi: Suatu Pengantar. Jakarta: PT. Raja Grafindo Persada.

Taylor, Shelley, E., Peplau, L. A. \& Sears, D. O. (2009). Psikologi Sosial Edisi Kedua Belas, Jakarta: Kencana.

Veiel, H. O. \& Baumann,U. (1992). The meaning and measurement of social Winarsunu, T. (2007). Statistika Dalam Penelitian Psikologi dan Pendidikan.

Wangmuba, J.K (2009). Sumber Dukungan Sosial. Bandung: Alfabeta.

Winarnu, T. (2007). Statistika Dalam Penelitian Psikologi dan Pendidikan. UMM Press.

Young, K, (1998), Caught in the Net: How to Recognize the Signs of Internet Addiction and a Winning Strategy for Recovery, New York, NY: Wiley. 